\title{
Virus Infections and Respiratory Disease of Childhood
}

\author{
P. S. GARDNER \\ From the Department of Virology, Royal Victoria Infirmary, and \\ University of Newcastle upon Tyne, Newcastle upon Tyne
}

Respiratory disease has always been present amongst children, but the importance of viruses in its causation is a recent discovery. An historical approach shows the rapid development of our knowledge of the part played by viruses in the aetiology of respiratory infection. The three influenza viruses were the first of the respiratory viruses to be discovered: influenza $A$ by Smith, Andrewes, and Laidlaw in 1933; influenza B independently by Francis and by Magill in 1940; and influenza $\mathrm{C}$ by Taylor in 1949. It was, however, the application of tissue culture techniques to virology by Enders, Weller, and Robbins in 1949 which opened the gate for a flood of new viruses. Members of the adenovirus group were found as latent infections of tonsils and adenoids by Rowe and his colleagues in 1953. A different member of this new group was associated with an outbreak of respiratory disease among military recruits (Hilleman and Werner, 1954). The next group to be discovered was parainfluenza viruses, pioneered by Chanock and his colleagues in the United States in 1958, and by Beale et al. in Canada in the same year. These viruses had originally been called the haemadsorption viruses because of their method of identification. Perhaps the most important find of all was the discovery and association of respiratory syncytial virus with severe respiratory disease in childhood, again by Chanock and his colleagues in 1961. This virus had previously been described in 1956 by Morris, Blount, and Savage as one which had caused a coryza in chimpanzees. The name respiratory syncytial virus (RSV) is descriptive of the appearance produced when it is inoculated on to the appropriate tissue cultures, and, as far more children were found to suffer from this virus than chimpanzees, the name was accordingly changed. This period also saw the isolation of the first members of the rhinovirus group by Tyrrell and his colleagues (1960), which now number well over 80 distinct antigenic types.

The association of a number of miscellaneous members of the Coxsackie and echovirus groups with respiratory disease was also found at this time (Philipson, 1958; Heggie et al., 1960; Kendall, Cook, and Stone, 1960).

The latest addition to the complex virus picture is a number of viruses similar to the avian bronchitis virus and mouse hepatitis virus (McIntosh, Becker, and Chanock, 1967) which are isolated in human organ culture. Bradburne, Bynoe, and Tyrrell (1967) showed that one of these viruses could cause cold-like illnesses in volunteers. The relation of this group to the fowl and murine viruses has still to be determined, but it appears that a new family of respiratory viruses capable of causing human disease has been discovered.

A study of children's respiratory disease should start in the home. The late Sir James Spence initiated the great $\mathbf{1 0 0 0}$ family study in Newcastle which has given a wealth of information about childhood disease, including respiratory infections (Miller et al., 1960). The investigation began with the study of 847 children observed from birth to 5 years and, between them, these had a total of 4147 respiratory illnesses. In addition, there were 8 fatal cases of pneumonia, all occurring within the first year of life. Unfortunately, at the time of the 1000 family study, virology was in its infancy and facilities were not available for the investigation of those viruses which were then known. Nevertheless, this survey gave the first insight into the extent of respiratory disease in the family and the importance of respiratory infection in relation to the whole of childhood disease. This is well illustrated in Fig. 1.

Dingle, Badger, and Jordan (1964) initiated a 10-year study of civilian families in Cleveland, Ohio, in 1948, the emphasis being placed on the occurrence and behaviour of illness over a period of years. These workers believed that a family was the basic epidemiological unit, having the major influence on health and disease. Like the 1000 family study mentioned above, this investiga- 


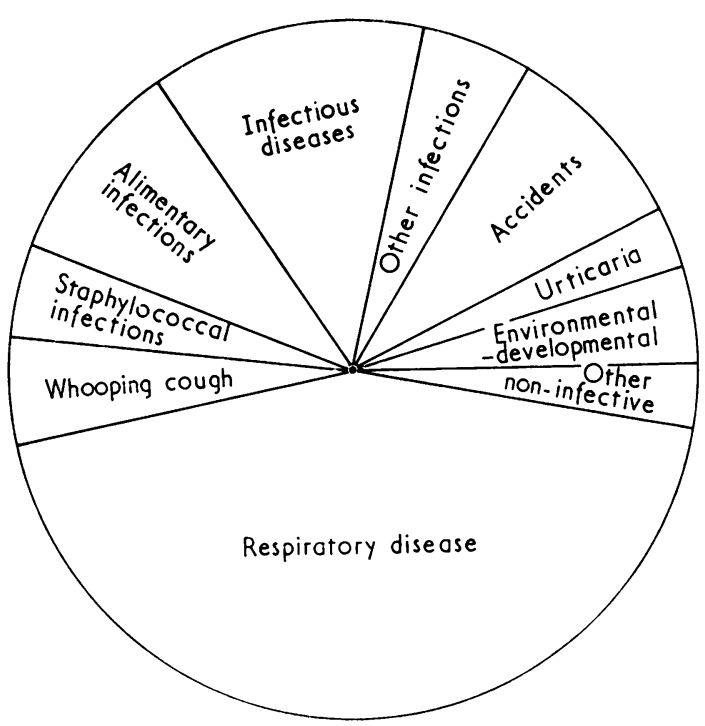

Fig. 1.-Newcastle upon Tyne, 1947-1952. Infective and non-infective illnesses in 847 children in the first 5 years.

[Reproduced from Growing up in Newcastle upon Tyne, with kind permission of the publishers, Oxford University Press, and the Nuffield Foundation.]

tion was also limited by the lack of knowledge at that time of aetiological agents such as RSV and rhinoviruses, which are now considered to be of prime importance.

Recently, the Medical Research Council's Working Party on Acute Respiratory Virus Infections (1965) pursued the investigation of respiratory virus infection in general practice, in an attempt to answer questions on the causation of respiratory illness in the home.

An enterprising and instructive investigation of parainfluenza in general practice was carried out in Cambridge by Banatvala, Anderson, and Reiss (1964) and has shown the importance of this group of viruses in the home.

Nursery schools have also afforded a means of studying virus infections in children. The best known example is the American welfare nursery known as Junior Village, where longitudinal surveillance of microbial and disease experience is under study. 8 outbreaks of parainfluenza infections over a 3-year period occurred in Junior Village, and problems related to virus spread and immunity were studied (Bell et al., 1961).

Perhaps the most fruitful source of our knowledge of the causation of respiratory disease in childhood has come from work on children admitted to hospital. Hospital studies of respiratory virus infections have been carried out in a number of centres both in the United States and in this country. In the United States, Chanock and his colleagues in Washington (1961) were again in the forefront, as were McClelland and her colleagues in Philadelphia (1961) and Beem and his associates in Chicago (1960). In this country, hospital studies of virus respiratory diseases of children were started at a number of centres including Newcastle (Gardner et al., 1960; Andrew and Gardner, 1963), Manchester (Holzel et al., 1963, 1965), Bristol (Clarke et al., 1964), and Glasgow (Stott et al., 1967; Grist, Ross, and Stott, 1967). These studies have been useful for attempting to define the clinical categories of illness bringing children into hospital and the virus agents associated with these conditions, and also as a comparison with respiratory illness in general practice, and they give guidance as to which virus infections are more prone to necessitate hospital treatment. The Medical Research Council has sponsored this investigation in 14 hospital centres in various parts of the country as a direct follow-up to the investigation in general practice.

Having thus listed the viruses that have been associated with respiratory illness and the epidemiological methods employed to study them, the remainder of this review is devoted to presenting a contemporary picture of the part played by viruses in respiratory illness of children.

We can best place both our knowledge and our ignorance into perspective by considering a number of questions: Which viruses are found in the respiratory tract and what is their significance in the causation of respiratory disease? What are the methods by which the laboratory achieves evidence of virus infection? What is the relation of respiratory viruses to clinical categories of respiratory illness and to death from respiratory disease? Can the information so gathered affect our views on management and treatment and give us hope for the prevention of infection in the near future?

\section{Significance of Viruses in the Upper Respiratory Tract}

One of the fundamental properties of a virus is its need to exist within living cells: the survival time of many viruses, especially those which are believed to cause respiratory disease, is extremely short when removed from living cells. This connexion between viruses and cells has led to a concept that the presence of a virus in the body must denote pathogenic significance. The idea that a virus occurs more frequently in diseased people is a truism which needs closer examination and, therefore, 
significance of the presence of viruses in the throat and naso-pharynx must be reconsidered. One method is to compare children suffering from respiratory disease with those affected by nonrespiratory conditions or without any evidence of illness (Chanock et al., 1961; Holzel et al., 1965). Other methods include the study of the aetiology of outbreaks (Carmichael, McGuckin, and Gardner, 1968), the examination of the effect of introducing viruses of doubtful pathogenic significance into human volunteers (Jackson et al., 1963), and the investigation of closed communities of children into which, inadvertently, a virus may be introduced (Wolontis, Tunevall, and Sterner, 1967).

The viruses which may cause acute repiratory disease are usually sought in the secretions of the upper respiratory tract: these may take the form of nasal and cough swabs, particularly from children, gargles from older children and adults, and occasionally sputa. However, the relation of the presence of viruses in the upper respiratory tract to the causation of disease in the lower respiratory tract must be considered.

Certain viruses are of undoubted pathogenic significance: careful comparison with control populations has shown that RSV is such a virus (Chanock et al., 1961). 'Controls' are difficult to select as they must be of the same age and sex as the patients with respiratory disease. They should also be used at the same time of the year and come from the same geographical area. The 'controls' must not be suffering from a respiratory disease or from an illness which may be associated with potential respiratory viruses: for example, it has been demonstrated that intussusception is associated with adenovirus infection (Gardner et al., 1962). The type of child suitable for selection as a 'control' may be one suffering from trauma, a hernia, repair of congenital defect, behaviour problems, etc.: debilitated children with malignant conditions would not be suitable as they are prone to acquire a wide variety of virus infections. These criteria have been used in Newcastle upon Tyne to select the 'control' group of children (Newcastle upon Tyne Hospital Respiratory Survey, 1959-67).

Material for virus isolation is obtained from the 'control' children preferably before entering the ward, but always within 24 hours of admission. After their specimens have been taken, the children are observed for a minimum of 48 hours, preferably for 7 days, to see if they develop any respiratory symptoms. Should they do so, they cannot act as 'controls'.

Many workers feel that children admitted to hospital are not normal children and question their use as 'controls', but the selection of 'control' children from other sources presents even greater problems.

Children attending welfare clinics have been used, but such clinics are often situated in an area far removed from the virus laboratory. Residential nurseries or schools should never be used as viruses are continually being circulated among the inmates (Gardner, Wright, and Hale, 1961; Gardner and Cooper, 1964). The normal child in his home environment would form the ideal 'control', but is not readily available.

Problems will arise with such viruses as Herpesvirus hominis in that they seem to occur more commonly amongst children with respiratory disease when compared with 'controls', but the difference is such that statistical significance is not reached.

There are also groups of viruses which occur as frequently in children with respiratory disease as in those without, but it cannot therefore be argued that, because this occurs, the virus involved will not cause illness. Polioviruses, for example, only exceptionally cause paralysis, though the number of normal children excreting these viruses may be considerable and, if only a comparison with controls had been used, the aetiological relation of poliovirus to paralysis might not have been discovered.

\section{Approach and Attitude to Respiratory Disease}

The justification for precise clinical definitions could not be better expressed than by the following quotation from Growing $U p$ in Newcastle upon Tyne (Miller et al., 1960).

'Our approach throughout has been based upon four premises. The first is that the interdependence of clinical description and the measurement of incidence justifies our division of respiratory disease into particular clinical categories. The second is that diseases can be recognized and defined in epidemiological as well as in pathological and clinical terms. The third is that the family and social environment influences the risk of occurrence, the severity, the persistence, and the outcome of many diseases. The fourth and last premise is that disease in a child must always be seen as a disturbance of the processes of growth and development: this is expressed in the changing patterns of clinical response at different ages, and in the characteristic sequence of clinical illnesses which emerges in certain individual children.'

The definitions expressed in this work have formed the basis of those used in Newcastle upon Tyne both in 1960 and in the subsequent long-term studies. These definitions have been adapted in the Medical Research Council's investigation of children admitted to hospital with respiratory disease. The views expressed in this quotation also led us to 
look at the various environmental and social factors which might influence virus disease in childhood.

\section{Clinical Definitions}

We have divided respiratory disease into 5 categories: upper respiratory tract infections; croup; acute bronchitis; acute bronchiolitis; and pneumonia.

Upper respiratory tract infections. This category contains a number of different upper respiratory infections. Colds are illnesses whose main feature is a watery, mucoid, or purulent nasal discharge. The severe cold may be associated with a moderate pyrexia. Pharyngitis is defined as a generalized erythema of the pharynx without localization in the tonsils and without the signs of a cold: the illness is usually associated with fever and malaise. Tonsillitis is a local infection of the tonsils which are red and swollen and often show an exudate: fever is often prominent. The last member of this group is otitis media, the main feature of which is redness of the drum which shows swelling and often a purulent discharge. Earache and fever are associated with this illness, which may be primary, though it may be secondary to other respiratory symptoms.

Croup or laryngitis or laryngotracheitis. This illness is often preceded by a cold, but the main symptoms are pyrexia, hoarseness, croaking cough, and stridor. Restlessness, pallor, or cyanosis are present in the most severe forms which are indicative of anoxia.

Acute bronchitis. This is a febrile illness whose main features are cough, often associated with wheezing and widespread rhonchi: râles are often present.

Acute bronchiolitis. This is an acute respiratory disease affecting infants and young children and usually occurs in epidemics. The main features are coryzal symptoms which have preceded the major illness by between 24 hours and several days, and this is quickly followed by the development of severe symptoms and signs. Fever is variable but respirations are rapid, there is a frequent, harsh, exhausting cough, respiratory wheeze, and, in most cases, fine râles are widespread throughout the lungs. The main physical sign is pulmonary overdistension, with costal recession. Chest $x$-ray will usually confirm the pulmonary overdistension and, in a few cases, there may be linear areas of collapse.
Pneumonia. In young children this is an acute respiratory disease associated with pyrexia, cyanosis, restlessness, and prostration: a cough is often present and the respirations are rapid. Clinical evidence of consolidation is only present in a small number of those affected, the main signs in the lungs being diminished air entry and the presence of râles. $X$-rays show shadows which may represent lobular, segmental, or lobar consolidation. In older children the disease may be characterized by a more insidious onset, and signs such as cough and râles may persist for several weeks.

\section{Factors Influencing Virus Infections of Childhood}

There are many epidemiological factors besides microbiological agents which influence the occurrence of acute respiratory disease in childhood. Those most applicable to this review are described.

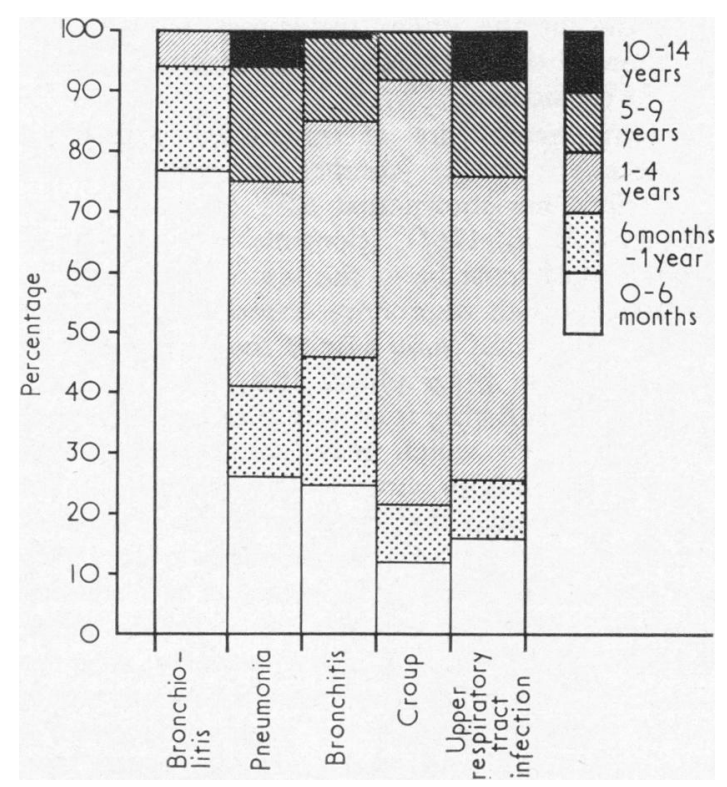

FIG. 2.-Age distribution for each clinical category.

Age. In hospital, the severest illnesses occur mainly in the very young child. Some children between 1 and 4 years are admitted with mild respiratory illnesses, such as upper respiratory tract infection, but which are complicated by a convulsion. Fig. 2 shows the age distribution among the clinical categories. Bronchiolitis is a disease of those under 1 year: pneumonia and bronchitis are spread evenly throughout each age-group: croup is a disease mainly affecting those between 1 and 4 years, as is upper respiratory disease. The 
admission of children with upper respiratory disease has been mainly determined by the occurrence of associated complications such as convulsions and diarrhoea. These figures are based on the work in Newcastle over the past few years (Newcastle upon Tyne Hospital Respiratory Survey, 1959-67), but other workers elsewhere have found similar figures (Holzel et al., 1963, 1965; Chanock et al., 1961).

Sex. We have consistently found that more male children are affected with acute respiratory disease and admitted to hospital than females, the proportion being that of $60: 40$. This sex difference was observed for all types of clinical categories of respiratory disease, and the increased susceptibility of male children occurred in all age-groups. Moss, Adams, and Tobin (1963) found, in a serological survey, that 13 of 15 children with respiratory infections were male. It has also been known for some time that male children are more predisposed to meningitis than females (Lindsay, Rice, and Selinger, 1940; Koch, Kogut, and Asay, 1961). As with respiratory disease, the reason for this is unknown.

Birthweight. A further factor is the birthweight which seems to be of importance in determining the susceptibility of young children to respiratory infection. In Newcastle, it was found that many of the very young children with respiratory infections had birthweights of less than $2.5 \mathrm{~kg}$. and that few weighed more than $3.4 \mathrm{~kg}$. at birth (Newcastle upon Tyne Hospital Respiratory Survey, 1959-67). This observation is in agreement with that of Douglas and Blomfield (1958) who also found that children weighing less than $2.5 \mathrm{~kg}$. at birth were more susceptible to all types of acute respiratory infection.

Socio-economic status. Studies in Newcastle were also directed at the investigation of the relation of socio-economic status and family size to respiratory infection (Newcastle upon Tyne Hospital Respiratory Survey, 1959-67). More children were admitted to hospital from families of 5 or more, and those in the lower socio-economic groups were found to be more susceptible to respiratory infection than those from the upper socio-economic groups. These observations are in agreement with the investigations of other workers such as Douglas and Blomfield (1958) and Dingle et al. (1964).

Season. Season obviously affects the incidence of respiratory disease. Epidemics of acute bronchio- litis occur only in the winter months coinciding with a fall in the environmental temperature. In this country epidemics last about a month, with sporadic cases between outbreaks. These epidemics often occur in November and again in January or February, but there have been years with little evidence of acute bronchiolitis and no outbreaks. The absence of bronchiolitis in the community has coincided with mild winters (Chanock et al., 1961; Sultan, 1966; Holzel et al., 1965; Lidwell, Morgan, and Williams, 1965; Newcastle upon Tyne Hospital Respiratory Survey, 1959-67).

\section{Laboratory Aspects}

The primary function of the laboratory is to identify the viruses associated with those clinical categories of respiratory disease which have been defined. Secondly, it must study these diseases throughout the year and observe any monthly or yearly variations. Thirdly, it should observe the frequency with which each virus is capable of causing respiratory disease, and lastly, whether a particular virus agent is specifically associated with a particular clinical syndrome. This general aetiological knowledge is essential background information for the development of prophylactic measures to control respiratory virus disease.

The introduction and development of immunization procedures and anti-viral agents is dependent on the understanding of factors governing the susceptibility to virus infections and frequency of occurrence of particular viruses. The excessive and unecessary use of antibiotics when pathogenic bacteria are not involved is to be deprecated. Not only is it uneconomic, but it may be harmful and encourage the development of resistant strains of bacteria. One should concentrate on other measures such as oxygen therapy which can be lifesaving.

As these preliminary views depend on the accurate identification of the agents involved by all possible techniques, the further development of rapid diagnostic techniques will be of great importance.

The collection of specimens for the diagnosis of respiratory virus disease has undergone a change over the past few years. At one time, specimens were frozen in cardice at the patient's bedside, but in recent years it has been found that such treatment will damage a number of viruses, especially RSV and parainfluenza viruses (Beem et al., 1960; Chanock et al., 1961; Andrew and Gardner, 1963). Specimens should be transported in a medium such as Hanks containing antibiotics and $2 \%$ bovine albumin, brought on melting ice to the 
laboratory and inoculated on to the appropriate cell lines as quickly as possible, in our laboratory always within half an hour. Specimens taken from young children have been cough or gagging swabs (Gardner et al., 1960; Medical Research Council's Working Party on Acute Respiratory Virus Infection, 1965) and naso-pharyngeal secretions (McQuillin and Gardner, 1968).

\section{Cell lines and isolation techniques.} Material from the upper respiratory tract is inoculated on to different tissue culture cell lines and several have been used. These cell lines should always include one of continuous human origin, and HeLa cells (Bristol) are particularly popular in this country for the isolation of RSV (Peacock and Clarke, 1961; Holzel et al., 1963; Andrew and Gardner, 1963). HEp.2 cells are another line widely used both in this country and in the United States (Beem et al., 1960; Elderkin et al., 1965). K.B. cells have also been used by other workers (Vargosko et al., 1965). At least two of these cell lines will cater for the isolation of RSV, adenoviruses, herpesvirus, and even some of the picornaviruses. Laboratories also use rhesus monkey kidney cells, particularly for the isolation of parainfluenza viruses and influenza, by using the haemadsorption technique based on the original method of Vogel and Shelokov (1957). Many laboratories have now abandoned fertile hens' eggs for the routine isolation of influenza and rely on their monkey kidney cultures. Monkey kidney cells may also grow some strains of rhinovirus as well as Coxsackie and echoviruses associated with respiratory illnesses. Human diploid cells are used by many laboratories in an attempt to isolate the $\mathrm{H}$ strain of rhinovirus (Hayflick and Moorhead, 1961; Tyrrell et al., 1962). The strain most commonly employed is W.I.38, which is a semicontinuous embryo lung diploid cell. Monkey kidney cells and human diploid cells are normally incubated at $33^{\circ} \mathrm{C}$. on a roller drum, in order to encourage the isolation of rhinoviruses. Tyrrell, Bynoe, and Hoorn (1968) have developed the use of human organ cultures and have thereby increased the range of rhinoviruses which can be isolated, but human embryo trachea cultures, at this stage, cannot be applied routinely.

The investigators quoted have adequately described their methods of identifying viruses isolated, usually by complement-fixation or neutralization tests.

Serological investigations. The complementfixation test is the main serological method of investigating childhood respiratory disease. This type of work is hampered by two factors. In the first place, very young children are reputed to be poor antibody producers (Parrott et al., 1961), though Gardner, Elderkin, and Wall in 1964 found that, by the age of 3 months, the majority of children infected with RSV were capable of antibody response. The other difficulty with young children is obtaining suitable quantities of blood, though, by using heel stabs, one can obtain sufficient blood for microtechniques. It is important to obtain paired sera taken at an interval of at least 7 to 10 days. Ross et al. (1964) found that a longer interval may give more fourfold rises of antibody titre. The method used by most laboratories in this country is based on that described by Bradstreet and Taylor (1962), and the virus agents which are normally investigated by complement-fixation tests are influenza A, B, and C, adenovirus, parainfluenza I (Sendai), mumps, RSV, and measles. Other agents normally included with these virus antigens are those for Rickettsia burneti, psittacosis, and Mycoplasma pneumoniae.

Neutralization tests have been used by some workers (Chanock et al., 1961) for the investigation of serum antibody levels for particular viruses. Neutralizing antibodies are usually measured to give a more complete picture of the immune state of a patient.

Rapid diagnosis. Rapid diagnosis has been the goal of clinical virologists for many years. One method is by electron microscopy and the most recent attempt was by Doane and his colleagues (1967) for the diagnosis of paramyxovirus infections, but this method will only place a virus into its morphological group.

A few workers have attempted to diagnose respiratory viruses rapidly by use of immunofluorescence. Most have confined their interest to one virus because of the variety of respiratory viruses present in the upper respiratory tract. One of the first to use this method was Liu (1956) for the diagnosis of influenza. Recently, Hers, Van der Kuip, and Masurel (1968) also used this technique in the rapid diagnosis of this virus, while McQuillin and Gardner (1968) have shown that similar methods can be applied for the rapid diagnosis of RSV. The latter workers prepared cell smears from naso-pharyngeal secretions aspirated from children with severe lower respiratory disease: they also studied series of tissue cultures inoculated with specimens from similar patients at intervals during the first week of incubation. To these materials they applied the indirect fluorescent 
TABLE I

Virus Isolations from Upper Respiratory Tract in 1137 Children Investigated

\begin{tabular}{|c|c|c|c|c|c|c|c|c|c|c|c|c|}
\hline & RSV & $\begin{array}{c}\text { Adeno- } \\
\text { viruses }\end{array}$ & $\begin{array}{c}\text { Para- } \\
\text { influenza } \\
\text { Viruses }\end{array}$ & $\begin{array}{l}\text { Influenza } \\
\text { Viruses }\end{array}$ & $\begin{array}{c}\text { Coxsackie } \\
\text { Viruses }\end{array}$ & $\begin{array}{l}\text { Polio } \\
\text { Viruses }\end{array}$ & $\begin{array}{l}\text { Echo } \\
\text { Viruses }\end{array}$ & $\begin{array}{c}\text { Herpes } \\
\text { Virus }\end{array}$ & $\begin{array}{l}\text { Rhinovirus } \\
\text { (H Strain) }\end{array}$ & $\begin{array}{l}\text { Myco- } \\
\text { plasma }\end{array}$ & $\begin{array}{c}\text { Total } \\
\text { No. } \\
\text { Swabbed }\end{array}$ & $\begin{array}{c}\% \\
\text { Positive } \\
\text { Isola- } \\
\text { tions }\end{array}$ \\
\hline $\begin{array}{l}\text { Pneumonia } \\
\text { Bronchio- } \\
\text { litis } \\
\text { Bronchitis } \\
\text { Croup } \\
\text { Upper resp. } \\
\quad \text { tract } \\
\text { infection }\end{array}$ & $\begin{array}{r}36 \\
93 \\
28 \\
5 \\
\\
27\end{array}$ & $\begin{array}{l}6 \\
2 \\
8 \\
- \\
\\
27\end{array}$ & $\begin{array}{r}4 \\
1 \\
4 \\
3 \\
\\
\\
10\end{array}$ & $\begin{array}{l}1 \\
= \\
=\end{array}$ & $\begin{array}{l}2 \\
- \\
- \\
3\end{array}$ & $\begin{array}{r}1 \\
-1 \\
3\end{array}$ & $\begin{array}{r}1 \\
- \\
5\end{array}$ & $\begin{array}{r}10 \\
2 \\
6 \\
2 \\
\\
9\end{array}$ & $\begin{array}{l}1 \\
1 \\
1 \\
-\end{array}$ & $\begin{array}{l}- \\
-\end{array}$ & $\begin{array}{r}284 \\
\\
258 \\
185 \\
54 \\
\\
\\
\\
356\end{array}$ & $\begin{array}{l}22 \\
\\
38 \\
26 \\
20 \\
\\
\\
\\
25\end{array}$ \\
\hline $\begin{array}{l}\text { Total } \\
\text { virus } \\
\text { isolations }\end{array}$ & 189 & 43 & 22 & 1 & 5 & 5 & 7 & 29 & 7 & - & 1137 & 27 \\
\hline Controls & 2 & 7 & 2 & - & - & - & 1 & 3 & - & - & 205 & 7 \\
\hline
\end{tabular}

antibody. technique. A specific rabbit antiserum against RSV was applied to the suspected material on slides. This serum had been previously absorbed to remove all factors that might have reacted with the tissue culture cells. The slide was then thoroughly washed and an anti-rabbit globulin conjugated with fluorescein was applied. If RSV was present in the cells then specific fluorescence was observed. These workers extended their series and found that, not only was the diagnosis of RSV more rapid by the fluorescent antibody technique, but also that as many cases could be diagnosed in

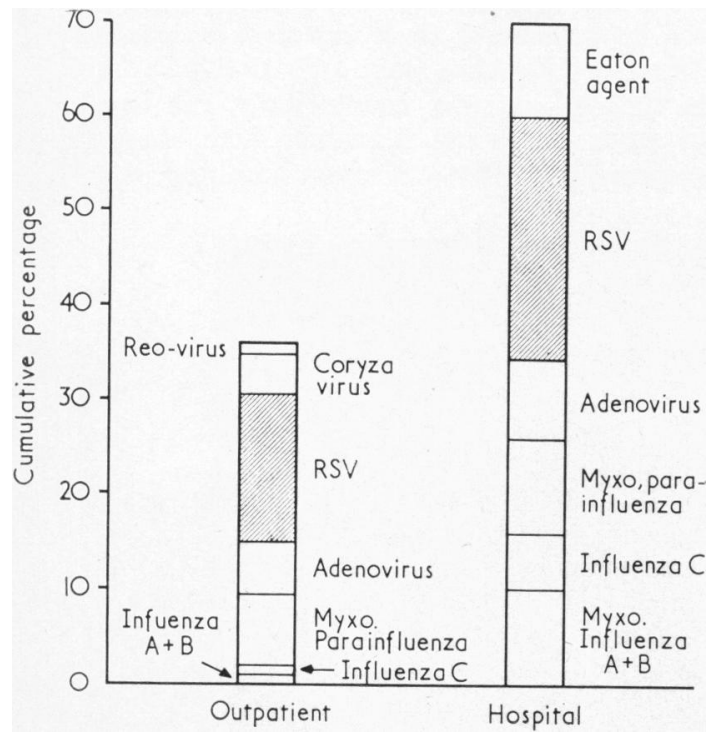

FIG. 3-Over-all estimate of relevant importance of respiratory disease agents Hilleman (1963). [By courtesy of the Editor of the American Review of Respiratory Disease.] the first week as the more usual laboratory methods diagnose in, a month (Gardner and McQuillin, 1968).

\section{Relation of Virus Infections to Respiratory Illness}

The virus agents associated with respiratory disease have been studied for many years and two factors influence such studies. In the first place, investigations must be carried out over periods of more than one year, since the incidence of a virus may vary from year to year, e.g. influenza may only play a part in the aetiology of respiratory infections every few years, and parainfluenza viruses may also occur in cycles of more than one year. Secondly, surveys will depend on the techniques available at the time they are taking place. In this country, no survey of respiratory virus disease carried out before 1961 will include mention of RSV, while investigations taking place up to a year later will be unlikely to contain any information on rhinoviruses.

Fig. 3 has been adapted from the work of Hilleman (1963) and shows the importance of viruses as a cause of hospital admissions and out-patient attendances.

The Medical Research Council's Working Party on Acute Respiratory Virus Infection (1965) showed the incidence of viruses in childhood infections in the home. At the moment, figures for admissions of children with acute respiratory virus infections at 14 hospital centres in this country are being analysed, but no details are yet available. Newcastle was one of the centres included in this survey and our figures (Table I), taken from a study spread over $3 \frac{1}{2}$ years, show the fundamental part that RSV plays in such conditions. 
The main difference between the Newcastle upon Tyne Hospital Respiratory Survey (1959-67) and the Medical Research Council Survey on illness in the home (1965) was the much lower incidence of RSV and the higher incidence of rhinovirus infections in the home when compared with hospital admissions.

Respiratory syncytial virus. This is the major pathogen encountered in respiratory diseases of childhood. There is no doubt of its significance, not only from our own figures, but particularly from those of Chanock et al. (1961) and other workers such as Holzel et al. (1963). Chanock and his colleagues showed that, between the ages of 0 and 6 months, $42 \%$ of bronchiolitis, $24 \%$ of pneumonia, and $12 \%$ of minor respiratory illness was due to infection with RSV. Only $1 \%$ of 'controls' with no respiratory illness showed evidence of being infected with this virus. Recent research has clearly shown that it causes the majority of virus respiratory disease in children under the age of 1 year, and is still a predominant pathogen in those from 1 to 2 years.

The undoubted importance of RSV as a respiratory pathogen has led us to develop the fluorescent antibody technique for its rapid diagnosis (McQuillin and Gardner, 1968; Gardner and McQuillin, 1968). Diseases such as bronchiolitis and pneumonia, when affecting the young child, produce an abundance of nasopharyngeal secretion, which can be aspirated. Fig. 4 shows typical, positively fluorescing cells from a naso-pharyngeal secretion compared with an appropriate negative control. In a recent series, 22 children under the age of 1 year with bronchiolitis were examined. The naso- pharyngeal secretions from 15 of these children were positive for RSV on the day of admission by this technique and all were later confirmed by conventional techniques of isolation and serology, with only 1 negatively staining secretion subsequently proving positive on tissue culture. There were no false positives by the fluorescent antibody technique. 7 children suffering from pneumonia were also examined: secretions from 2 of these stained positively by the fluorescent antibody technique and from both RSV was later isolated. RSV was isolated from only 1 of the negatively staining secretions.

In severe lower respiratory disease, we believe that $90 \%$ of children with RSV infections can be diagnosed on the day of admission.

This method has also been extended and applied to tissue culture tubes inoculated with material from patients suffering from lower respiratory infections. Three tissue culture tubes were examined by the fluorescent antibody technique at intervals over the first 7 days. Two additional inoculated tissue culture tubes continued for at least 28 days' incubation for conventional virus isolations. By the fluorescent antibody technique, it was possible to give an aetiological diagnosis of RSV infection which was as accurate and sensitive as conventional isolation and serological techniques.

Parainfluenza viruses. It was due to the work of Chanock and his colleagues (1963) that the importance of these viruses was demonstrated. Their investigation from 1957 to 1962 of children in hospital showed, convincingly, the importance of types 1,2, and 3, which were shown to be responsible for $29 \%$ of croup admitted, but played

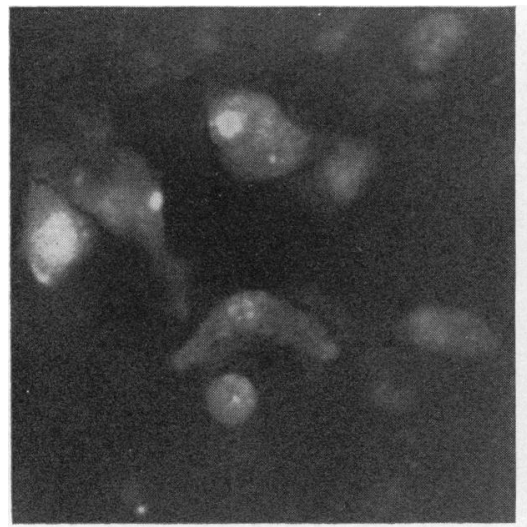

(a)

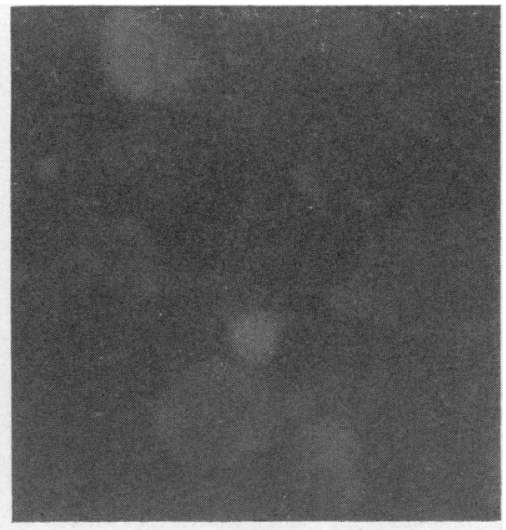

(b)

Fig. 4.-(a) Naso-pharyngeal secretion-respiratory syncytial virus shown as intracellular fluorescence. Compare with (b) control, negative for RSV. $(\times 400$. 
a small, though significant, part in both upper and severe lower respiratory disease. The incidence of the 3 types of parainfluenza in 5736 children with respiratory disease was $6 \cdot 1 \%$, compared with $0.5 \%$ occurring in 3528 children admitted to hospital without respiratory disease.

Similar figures were obtained in Holland by Van der Veen and Smeur (1961). Banatvala et al. (1964) looked at the incidence of parainfluenza viruses in the community, while information from the Medical Research Council Working Party on Acute Respiratory Virus Infection has confirmed their importance in respiratory disease in the community.

Influenza viruses. The role of these viruses as pathogens of acute respiratory disease needs no comment, but as far as children's admissions to hospital are concerned, they play only a minor and unimportant role. In the last $3 \frac{1}{2}$ years of the Newcastle survey they caused less than $1 \%$ of admissions which were all associated with pneumonia. The last 100 admissions of children with pneumonia coincided with an influenza $A$ outbreak in the city, and yet it accounted for only $4 \%$ of these illnesses. The incidence of respiratory admissions due to influenza A varies with the prevalence of influenza in the community, and the period of our survey was relatively free from influenza until the last winter.

The groups of viruses which we have discussed are, without doubt, respiratory pathogens occurring more frequently in children with acute respiratory disease and seldom in those without. The following groups of viruses to be examined are those for which some doubts exist.

Adenoviruses. Much has been written in the past about the pathogenic role of adenoviruses in respiratory disease. Adenoviruses appear to fall into two main groups, the first formed by types $3,4,7,14$, and 21 . These adenoviruses, though causing respiratory diseases at all ages, have been responsible for outbreaks in residential communities, particularly among military recruits and children at boarding school (Sobel et al., 1956; Kendall et al., 1957). These illnesses characteristically showed a triad of features: fever, pharyngitis, and conjunctivitis; though, on occassions, conjunctivitis was absent. Pneumonia, too, has been associated with these types, particularly 3 and 7 , and some fatal cases have been reported (Chany et al., 1958; Teng, 1960).

It is particularly with the second group of viruses, types $1,2,5$, and 6 , that doubt exists as to the role they may play in acute respiratory disease of childhood. In our Newcastle series of 1137 children who were investigated, the adenoviruses isolated from each clinical syndrome are shown in Table I. These were types 1, 2, and 5, but on one occasion, a type 3 was isolated. When these isolations were compared with those from 'controls', the only clinical category to show a significant difference was upper respiratory tract infections and, therefore, in lower respiratory tract disease, the role of adenoviruses types 1,2 , 5 , and 6 was unproven. More information on their pathogenicity may be obtained from investigating the lungs of children who die and from whom this group of viruses may be isolated (Deinhardt et al., 1958), but this is discussed in a later section.

The significance of adenoviruses in children with respiratory disease might be investigated in a residential nursery into which they are inadvertently introduced. The children could be observed to see what effect this virus has on their health, a study which has been attempted in Sweden (Wolontis et al., 1967), and which showed evidence of pathogenicity for adenovirus type 5 .

It is doubtful whether, by increasing the size of investigations and thereby the number of 'controls', the pathogenic role of this group of viruses would be clarified.

Herpesvirus hominis. The role of Herpesvirus hominis in respiratory disease has been neglected, but between $2 \%$ and $5 \%$ of children in hospital with acute respiratory disease have been noted to be infected with this virus by many workers (Clarke et al., 1964; Higgins, Boston, and Ellis, 1964; Holzel et al., 1965; Medical Research Council Working Party on Acute Respiratory Virus Infection, 1965). None of the children in our series had signs of conventional herpetic disease such as cold sores, gingivo-stomatitis, etc. but this virus was isolated from $2 \cdot 5 \%$ of respiratory cases. However, this figure was not statistically significant in the total number of acute respiratory infections when compared with the 'controls'. Neither did it reach significance in any of the individual clinical categories except pneumonia, where it was seen to occur twice as commonly as in 'controls', which could be considered at least suggestive of an aetiological association. The investigation of more patients infected with this virus might help to decide its relation to respiratory disease, particularly in pneumonia.

Picornaviruses. Echoviruses, Coxsackie viruses, and vaccine strains of polioviruses occurred in the cough swabs of $3.5 \%$ of children with upper respiratory disease in our investigations but only in $0.5 \%$ of 'controls'. The figures from our series 
are far too small for any conclusions to be drawn, but other workers have incriminated these viruses with respiratory disease: Coxsackie virus type B2 by Heggie et al. (1960); Coxsackie virus type B3 by Kendall, Cook, and Stone (1960); echovirus type 11 by Philipson (1958); echovirus type 20 by Cramblett et al. (1957); and recently, Coxsackie virus type $\mathrm{B} 2$ in a residential nursery in Newcastle upon Tyne (Carmichael et al., 1968). Coxsackie viruses are commonly excreted among children without symptoms, which makes interpretation difficult. Increasing the number of 'controls' and patients is hardly likely to clear this point, but once again the study of isolated outbreaks in nurseries and enclosed communities may be the best way of proving a pathogenic role for viruses in this group.

Rhinoviruses are associated with colds, as shown by Tyrrell et al. (1960) and Tyrrell and Bynoe (1961), and their pathogenicity has been confirmed by passage of suspected agents in volunteers (Bynoe et al., 1961). These viruses, however, still occur in children without respiratory disease, as shown by Stott et al. (1967) who found that they were as common in children with respiratory infection as in those with diarrhoea. Our own numbers of rhinovirus isolations are small but are in agreement with those of others (Hilleman et al., 1963), and we do not believe that they are an important cause of lower respiratory disease.

\section{Relationship of Bacteria to Acute Respiratory Infection}

In many respiratory infections the role of bacteria is difficult to assess (Nichol and Cherry, 1967; Loda et al., 1968). The bacteriological investigation of respiratory infections can be subdivided into the study of acute upper and acute lower respiratory infections.

In acute upper respiratory infections, the swabs are obtained directly from the site of infection, which makes interpretation of results more specific. $\beta$-haemolytic streptococci and Staphylococcus pyogenes have been incriminated in some of these cases, but there are still many where no bacterial cause can be found, many of these being due to virus infection (Medical Research Council's Working Party on Acute Respiratory Virus Infection, 1965).

Many organisms have been found in acute lower respiratory tract infection, particularly pneumococci, Staphylococcus pyogenes, and Haemophilus influenzae, which are all known pathogens. It is difficult to acquire specimens from the lower respiratory tract, especially in young children, though in older children and adults sputa may be obtained. In some cases, blood culture might be helpful, and in others fluid from effusions or empyemas. Specimens from necropsies of lungs might show the presence of pathogenic bacteria. Because of the obvious difficulties, specimens normally obtained from children with acute lower respiratory infections are taken from the upper respiratory tract, and pathogenic bacteria found there must be regarded with suspicion, as they do not necessarily imply a causative role. These organisms may be potential pathogens but they can also be found to the same extent in the upper respiratory tract of healthy children. This was shown in an extensive survey by Masters et al. (1958) and Brimblecombe et al. (1958), which was conducted amongst children in the Paddington area of London. Our own work shows that potentially pathogenic bacteria can be recovered from children with respiratory disease with much the same frequency as those quoted for normal children.

Staphylococcus pyogenes is a cause of pneumonia but there is no evidence of it being associated with any particular virus. There is, however, a close relation between influenza A during epidemic periods, and Staph. pyogenes and deaths from influenza are, in many cases, due to this association (Finland, Peterson, and Strauss, 1942; Miller and Jay, 1962).

A further difficulty in assessing the importance of bacteria in respiratory infection is that antibiotic therapy, which is given to more than $50 \%$ of the patients seen in Newcastle, may well eliminate pathogens from the lower respiratory tract before they are coughed up and found in the upper respiratory tract. Over many years of respiratory survey work in Newcastle we can find no evidence to support the claims of Wood, Buddingh, and Abberger (1954) and Sell (1960) that capsulated strains of Haemophilus influenzae are important in the aetiology of bronchiolitis. The observed types of haemophili found in our survey fall within the limits which are believed to be normal (Masters et al., 1958; Turk, 1963).

If bacteria are an important cause of acute respiratory disease, they should be found at the site of infection (Loda et al., 1968) or deaths from these conditions should show their overwhelming presence. In our experience in Newcastle this is not often so, and we therefore believe that a bacterial aetiology for severe respiratory infections is now the exception rather than the rule.

\section{Deaths Associated with Acute Respiratory Tract Infections in Childhood}

The Registrar General's statistical analysis for 
TABLE II

Pathological and Microbial Findings in 22 Respiratory Deaths

\begin{tabular}{|c|c|c|c|c|c|c|c|c|c|c|c|c|c|c|c|c|c|c|c|c|c|c|}
\hline \multirow[b]{2}{*}{ Case No. } & \multicolumn{7}{|c|}{ Bacterial Pneumonias } & \multicolumn{4}{|c|}{$\begin{array}{c}\text { Non-Bacterial } \\
\text { Pneumonias }\end{array}$} & \multirow[b]{2}{*}{12} & \multirow[b]{2}{*}{13} & \multicolumn{7}{|c|}{ Bronchiolitis } & \multicolumn{2}{|c|}{$\begin{array}{l}\text { Mild } \\
\text { Respira- } \\
\text { tory } \\
\text { Illness }\end{array}$} \\
\hline & 1 & 2 & 3 & 4 & 5 & 6 & 7 & 8 & 9 & 10 & 11 & & & 14 & 15 & 16 & 17 & 18 & 19 & 20 & 21 & 22 \\
\hline Age (mth.) & 21 & 4 & 5 & 1 & 1 & 36 & 1 & 1 & 1 & 4 & 6 & 1 & 2 & 3 & 3 & 4 & 5 & 6 & 9 & 22 & 2 & 4 \\
\hline $\begin{array}{l}\text { Congenital abnormalities } \\
\text { Heart } \\
\text { Others }\end{array}$ & & + & + & + & & & & & & + & + & & & & + & + & & & & & + & + \\
\hline $\begin{array}{l}\text { Potential bacterial } \\
\text { pathogens: } \\
\text { Ante mortem-upper } \\
\text { respiratory tract: } \\
\text { blood culture } \\
\text { Post mortem-heart/ } \\
\text { lung puncture } \\
\text { lung }\end{array}$ & $\mathrm{H}^{\star}$ & PS & $\operatorname{Pr}$ & A & $\begin{array}{l}\mathrm{S} \\
\mathrm{s} \\
\mathrm{S}\end{array}$ & $\mathbf{S}$ & $\mathbf{S}$ & $\begin{array}{l}- \\
-\end{array}$ & - & - & - & - & $\overline{-}$ & \begin{tabular}{c|}
- \\
$\cdots$
\end{tabular} & - & - & - & $\begin{array}{l}- \\
-\end{array}$ & $\cdots$ & - & - & $\begin{array}{l}- \\
- \\
-\end{array}$ \\
\hline $\begin{array}{l}\text { Ante mortem: } \\
\text { Viruses upper respira- } \\
\text { tory tract } \\
\text { Post mortem: } \\
\text { Viruses in lung }\end{array}$ & $\begin{array}{l}\mathbf{R} \\
\mathbf{R}\end{array}$ & - & - & - & - & & - & $\mathrm{R}$ & $\mathbf{R}$ & $\mathbf{R}$ & $\mathbf{R}$ & $\mathbf{R}$ & - & $\mathbf{R}$ & - & $\begin{array}{l}\mathbf{R} \\
\mathbf{R}\end{array}$ & -- & - & - & & $\mathbf{R}$ & - \\
\hline
\end{tabular}

$\mathrm{H}^{\star}$, Haemophilus influenzae type $\mathrm{b}$ isolated from epiglottis; $\mathrm{R}$, respiratory syncytial virus; $\mathrm{P}$, Ps. pyocyanea; $\mathrm{Pr}$, Proteus sp.; $\mathrm{S}$, Staphylococcus pyogenes; A, Streptococcus pyogenes Lancefield Group A; +, condition present; -, organism absent or no significant pathogen found.

England and Wales, 1966, showed that 2927 children under the age of 15 died in one year from acute respiratory tract infections and that 2372 of these were under the age of 1 year (Registrar General's Report, England and Wales, 1966): $28 \%$ of all deaths in childhood occurring after the first month of life were due to acute respiratory tract infections. Though the number of children who die from respiratory tract infection has decreased considerably since the introduction of antibiotic drugs, these deaths have certainly not been eliminated and the improvement obtained is very much less among infants than older children (Newcastle upon Tyne Annual Reports, Medical Officer of Health, 1931-65). These figures suggest that few of the deaths still occurring from acute respiratory tract infections are likely to be caused by a bacterial infection.

In the course of our surveys on respiratory tract infections in childhood in the Newcastle upon Tyne area, sufficient information was obtained about 22 children who died over a 26-month period to merit close analysis (Gardner et al., 1967). It was necessary for these children to have been admitted to hospital before they died, to have had a necropsy performed, and to have had both bacteriological and virological examinations carried out before and after death. The investigation was designed to acquire information on three subjects: the presence of any condition which might have made the child more liable to succumb to infection; the nature of the infecting organism; and any features of the child's clinical condition that might suggest the mechanism of death and measures that might have prevented it.

One of the problems of examining lungs of children bacteriologically at necropsy is the growth of coliforms and other Gram-negative organisms which are probably of no aetiological significance and may mask any causal organisms present; every effort was therefore made to obtain material from these children with minimal bacterial contamination. Blood cultures were examined from 2 of the children during life, and 11 further children had heart and lung punctures carried out within 15 minutes of death: this material was inoculated into Robertson's cooked meat medium and incubated as soon as possible. The heart and lung puncture material was not used for any virological examination as it was considered more important at this stage of knowledge to know if bacteria played any role in causing the death of children from acute respiratory infection. Instead, lung tissue was collected for virus culture from necropsy material. In addition, 11 of these children had cough swabs taken immediately on admission, which were examined as previously described. Table II summarizes the findings. 
The first 7 children apparently died from bacterial infections. Case 1 was a child with epiglottitis who was admitted in a moribund condition and breathing was maintained after admission by positive pressure ventilation. Haemophilus influenzae type b, the expected causal agent (Turk and May, 1967), was isolated at necropsy from a grossly inflamed epiglottis but, in addition, RSV was found in both the upper respiratory tract before death and in lung material after death: the latter might be accounted for by the prolonged positive pressure ventilation that this child received. Cases 2 and 3 had, for several weeks before death, received continuous antibiotic treatment for pulmonary mucoviscidosis and, in each case, highly antibiotic-resistant Gram-negative bacteria were found in the upper respiratory tract during life and in the lungs at necropsy, which showed terminal pneumonia. Case 4 was a child with multiple congenital haemangiomata. These became infected and the child died from a $\beta$-haemolytic group A streptococcal septicaemia and a septic pneumonia. Cases 5 and 6 both had a staphylococcal pneumonia which was characterized by lung abscesses, while Case 7 was admitted to hospital with a radiological picture highly suggestive of a staphylococcal pneumonia, staphylococci being present in the upper respiratory tract before death. This patient responded well to antibiotics but collapsed and died suddenly on the 8 th day after admission. Necropsy findings confirmed that she had a pneumonia which was now resolving, but her death was due to an unexplained area of myocardial necrosis.

Cases 8 to 11 had pneumonia for which no bacterial cause could be found: they died rapidly after admission and all had RSV isolated from the lungs at necropsy. 2 of these deaths were associated with severe congenital heart abnormalities.

Cases 12 to 20 had bronchiolitis. None was associated with bacteria which may have been potential pathogens, and RSV was isolated from 3. Only 2 children in this group had congenital abnormalities; 1 was cardiac, and 1 had previously undergone a lobectomy for congenital emphysema.

Cases 21 and 22 had only mild respiratory illnesses but they died suddenly on the 19th and 11th days, respectively, in hospital. Both had severe congenital cardiac defects amongst their other congenital abnormalities, and one child was infected with RSV.

This survey has been considered in some detail because it is the only comprehensive series of deaths of this kind which has been studied. Con- clusions are difficult to draw because only 22 children out of all those who died when suffering from respiratory tract infections were studied, but a number of points stand out.

(a) $40 \%$ of these children had major congenital abnormalities: 3 of the bacterial deaths were solely due to infection of congenital lesions, viz. 2 children with mucoviscidosis and 1 child with terminal septic pneumonia from infection of multiple congenital haemangiomata. The high proportion of children with such abnormalities in this series of fatal cases helps to explain why respiratory tract infections continue to have a relatively high mortality rate amongst young children.

(b) 6 deaths had demonstrable bacterial infections and a seventh had clinical evidence of a staphylococcal pneumonia, but died of a myocardial necrosis and should presumably be classed with the bacterial deaths. The 3 typical staphylococcal pneumonic deaths had no viruses associated with them, so far as could be determined. The Haemophilus influenzae death is a well-recognized condition which, fortunately, is rare, but its association with RSV is of some interest. RSV was isolated from 8 of the remaining 15 cases and, considering that all except 1 were isolated from lung material which may not have been taken from the body until 48 hours after death, the high isolation rate is remarkable. It was also the only virus to be found associated with the deaths in this series. The failure to find a bacterial cause for illness in these 15 children is all the more remarkable because only 4 had received antibiotics before admission. It is also unlikely that bacteria responsible for causing death from respiratory infection could not be detected in the lungs.

It would be reasonable to conclude from this series that bacteria are not commonly associated with fatal pneumonias of childhood and that RSV is the virus most likely to cause death, often in association with congenital abnormalities: bronchiolitis, though on occasions associated with congenital defects, may be a common cause of death due to RSV acting alone.

Shortly after this series was completed a child died with pneumonia. Adenovirus type 1 was isolated from the upper respiratory tract and from the lungs at necropsy. The histological picture of this case was identical to the series of five necropsies from which adenovirus type 7 was isolated and described so adequately by Becroft (1967). The changes were those of a necrotizing bronchitis, intranuclear inclusions, and a mononuclear cellular reaction. The recovery of adeno- 
viruses from the lungs of patients with pneumonia had been reported previously. These pneumonias were predominantly associated with the isolation of adenovirus types 3 and 7 (Chany et al., 1958; Teng, 1960), but, on occasions, types 1 and 2 have been isolated from lungs of similar fatal cases (Parker, Wilt, and Stackiw, 1961; Deinhardt et al., 1958). By 1963, 26 fatal cases of pneumonia in children attributed to adenovirus infection had been reported from the United States, England, France, Holland, and Japan (Van der Veen, 1963). A large epidemic of infantile pneumonia in Peking involving more than 3000 cases, with an estimated mortality of $15 \%$, was reported by Teng (1960). Hsiung (1963) described the histology of these cases. Other reports have come from Russia (Dreizen, Zhukova, and Kniazeva 1960) and Germany (Güthert, Meerback, and Wöckel, 1964). The evidence collected suggests that adenoviruses of the common types may be a cause of fatal respiratory infection. The few reported involving non-epidemic types such as 1 and 2 also produce convincing evidence that, in certain conditions, they are aetiological agents of pneumonia and can cause death. There has been no evidence of bacteria playing any part whatsoever in these cases.

When new antigenic types of influenza appear, there is an increase of severe and fatal pneumonias in persons of all ages. It is fully recognized that this is probably due, in the majority of cases, to infection by influenza in association with the staphylococcus. However, in infancy, the mortality rate is least, the main brunt of influenzal disease occurring during adolescence and early adult life (Francis, 1963).

The study of deaths from respiratory disease is not an end in itself. It should teach us what the commonest causes are and how they may be prevented. It should also give us guidance on the correct management and treatment to be followed in order to prevent its occurrence. The use of prophylactic vaccines may then be profitably explored. Such a study should also be a humiliating experience for us as doctors, for deaths, though few in number today, are the ultimate tragedy which can occur in the family unit.

\section{Management and Treatment}

In the absence of any specific therapy, the early recognition and precise treatment of hypoxia (Reynolds and Cook, 1963; Simpson and Flenley, 1967), dehydration (Disney et al., 1960), hyperpyrexia, and heart failure (Heycock and Noble, 1962; Elderkin et al., 1965; Holdaway, Romer, and Gardner, 1967) would considerably reduce mortality.
The use of antibiotics in acute respiratory disease is a vexed question. Our aetiological studies show that the great majority of such illnesses are of virus origin, and we also know that all viruses are completely resistant to the known antibiotics. Any antibiotics given in this condition are therefore not directed at eliminating the causative organism but to the prevention or treatment of any secondary bacterial invaders. It has become an established practice to give antibiotics to all patients admitted to hospital with acute respiratory disease, but this should now be reconsidered. Holdaway et al. (1967) expressed opposition to their routine use in bronchiolitis because they believed it to be a virus disease with no bacterial element, which was confirmed by their investigation of deaths. In their study, antibiotics were used selectively when there was radiological evidence of pneumonia or the presence of potentially pathogenic bacteria in the upper respiratory tract. The practice of these workers was to give benzyl penicillin and cloxacillin to every child for 24 to 48 hours until the results of radiographic and bacteriological investigations were known. If these were satisfactory, all antibiotics were stopped but were started if later clinical or radiological evidence suggested a developing pneumonia. In 80 consecutive cases of acute bronchiolitis in children, antibiotics did not need to be started, and this strengthens our conviction that, in this condition, they are unnecessary unless pathogenic bacteria or radiological evidence of consolidation are present.

The use of antibiotics in pneumonia needs further consideration. Though some 40 to $50 \%$ of pneumonia is of proven virus aetiology (Elderkin et al., 1965), cases due to bacteria still occur. In the series of deaths reported above, 6 bacterial pneumonias and 4 virus pneumonias were recorded, the latter having no bacteria associated with them. However, antibiotics, though unhelpful and sometimes harmful in virus pneumonia, will continue in use until the difficulty of determining with certainty and necessary speed the nature of the causative organism in each individual case is resolved.

The evidence from the surveys in Newcastle upon Tyne and from our series of deaths makes it unlikely that RSV infections are complicated by pathogenic bacteria. The new developments in the rapid diagnosis of RSV by immunofluorescent techniques become even more important for the rational management of these cases.

No effective antiviral drugs are yet available for the treatment of respiratory virus infection, though the treatment of Herpesvirus hominis by 
iododesoxyuridine indicates that progress is being made in this difficult field.

\section{Prevention of Respiratory Disease}

The inadequacy of specific treatment for virus respiratory disease is an incentive to examine preventative and prophylactic measures more fully. The development of such measures will depend on the enhancement of the natural immune mechanisms of the body. The role of antibody in the protection of the young child from infection must be considered in a number of ways.

The source of antibody may be maternal or it may be acquired from previous infections or immunization procedures. Maternal antibody is highly effective in protecting against many viral diseases, e.g. measles is rarely, if ever, seen in this country in children below the age of 6 months, and most of the other exanthemata are rare in the early months of life because of the mother's previous exposure to infection. However, severe lower respiratory disease shows a great predilection for children under the age of 6 months: $77 \%$ with bronchiolitis, $27 \%$ with pneumonia, and $24 \%$ with bronchitis were less than 6 months when admitted to Newcastle upon Tyne hospitals. These figures are close to those for the association of RSV with these clinical categories, which were $53 \%, 20 \%$, and $17 \%$, respectively (Newcastle upon Tyne Hospital Respiratory Survey, 1959-67). This suggests that maternal antibody plays little if any part in the protection of the infant from RSV infection. We know that the infant can produce humoral antibody to RSV infection from about 3 months of age onwards and that, by the age of 2 or 3 years, most children have been infected with this virus (Gardner et al., 1964; Hambling, 1964).

One of the unusual features of RSV infection is the high percentage of adult sera showing appreciable levels of RSV complement-fixing antibody (Hambling, 1964). Most complement-fixing antibody titres fall rapidly, and adults rarely show high titres to the common virus antigens unless recently infected. Therefore, it must be considered whether RSV antibodies are unusually long lasting, possibly with persistence of virus infection, or whether there is crossing with other unknown viruses sharing a common antigen; but the most likely explanation is that re-infections with RSV occur (Kravetz et al., 1961; Johnson et al., 1962).

A possible explanation of the absence of protection by maternal antibody and the frequency of re-infection is that humoral antibody does not protect while nasal antibody might. As long ago as 1940, Francis showed that nasal secretions contained antibodies against influenza (Francis, 1940b), as did Smorodintsev and Chalkina (1955) a few years later, and antibodies against rhinoviruses have been found in nasal secretions by Tyrrell (1963).

Usually, inoculation of a vaccine has coincided with the increased concentration of antibody in both nasal secretion and serum. However, infections in volunteers and patients by RSV and parainfluenza 3 have not resulted in protection, though they have high levels of antibody in their blood. Recently, there have been reports from the World Health Organization and Pan American Health Organization (Lancet, 1967) that natural infection could not be prevented by the parenteral administration of a killed RSV vaccine which produced circulating antibody. In fact, it appeared that children receiving the vaccine fared worse with natural infection than children receiving none: this could be interpreted as sensitization rather than immunization.

A similar experience occurred with Mycoplasma pneumoniae vaccine for, when those patients receiving vaccine but who produced no detectable antibody were challenged with live $M$. pneumoniae organisms, they suffered severe illness. Those who produced antibody to vaccine or those without antibody but who had received no vaccine before challenge suffered little or no illness (Smith, Friedwald, and Chanock, 1967).

Smith et al. (1966) had previously studied the relative protective factors of antibody in serum and nasal secretions of adult volunteers challenged with parainfluenza virus type 1 . Nasal antibodies proved to be a better index of resistance than those in serum. The failure of an inactive parainfluenza type 1 vaccine to produce antibodies in nasal secretions was associated with failure to prevent reinfection.

There is no information on the production of nasal antibodies by RSV but, by considering this work on parainfluenza virus type 1 , a possible reason for the failure of maternal antibodies to protect, becomes apparent and could explain the lack of effective protection by a killed RSV vaccine. It also suggests that a killed vaccine such as RSV or Mycoplasma pneumoniae might sensitize the patient instead of immunize. One might take this speculation a stage further and make the suggestion that the reason for the severity of bronchiolitis in infancy is because the declining maternal antibody is producing a sensitization on infection with RSV instead of protection.

The role played by the type of $\gamma$-globulin has not yet been considered. Tomasi et al. (1965) 
showed that the immune defences of mucous membrane depend on $\gamma \mathrm{A}$ (instead of the usual $\gamma \mathrm{G}$ ), with some $\gamma \mathrm{M}$ and possibly a little $\gamma \mathrm{A}$ in the blood. Moreover, the $\gamma \mathrm{A}$ in nasal secretions had not quite the same structure as that found in the serum (South et al., 1966). It appears that much of the neutralizing power of nasal secretions against rhinoviruses and polioviruses is due to the $\gamma \mathrm{A}$ antibody (Bellanti, Artenstein, and Buescher, 1965). The relation of RSV to these factors has so far not been considered, but work on this subject is awaited with great interest.

It is now believed that interferon plays an important part in the body's natural recovery from virus infections (Baron, 1966). It is not known whether RSV is sensitive to interferon or if it is even an interferon producer. This information is urgently needed in order to consider the prevention and treatment of infection by this virus. It has been shown that RSV is the virus most commonly associated with deaths from respiratory disease, and that a very high proportion of these children have congenital abnormalities. It might be that such children are defective in interferon production. Baron and Isaacs (1962) examined the lungs of patients who had died of an overwhelming influenza A pneumonia and could not find interferon. Though this investigation was uncontrolled, and it is difficult to see how adequate 'controls' could be found, the implication was that deaths in these cases might be due to defective interferon production.

The task of preventing respiratory virus infection in childhood is enormous. The large number of viruses which may be associated with such infections makes prevention by vaccines an impossibility. The use of a vaccine might be limited to a few of the more widespread and dangerous viruses, and RSV appears to be an obvious choice for consideration in this context. It has been pointed out that killed vaccines may not produce the desired effects and that sensitization may develop instead of protection. The majority of severe infections fall below the age of 6 months, when responses to killed vaccines may be minimal and the time available for a course is limited. Attempts will be made to produce a live attenuated RSV vaccine, but the difficulties in its testing will be considerable. No experimental animal is susceptible to this virus and the only suitable host is the young human infant: older children and adults, though susceptible, respond to virulent RSV with only a mild infection, even in the presence of antibody.

The use of interferon may well be entertained in the treatment of childhood respiratory disease.
So far, no trials have been reported and the curative effect of interferon at the height of illness must be in doubt. The hopeful line of approach to prevention may be the eventual use of interferon inducers. Two of the most promising are statolon, discovered by Kleinschmidt, Cline, and Murphy (1964), and helenine, discovered by Rytel, Shope, and Kilbourne (1966). The work of Lampson and his colleagues (1967) suggests that the active principle is a double-stranded RNA molecule, and giving minute amounts of this material to experimental animals led to interferon production within two hours.

The application of these experimental findings to patients is many years away, but there is a glimmer of hope for controlling virus respiratory disease of childhood in the future.

In this paper I have quoted freely from the Newcastle upon Tyne Hospital Respiratory Survey, 1959-67, to be submitted for publication shortly, and I would like to acknowledge the collaboration of many colleagues in this work, in particular, Professor S. D. M. Court, Drs. D. C. Turk, M. D. Holdaway, A. C. Romer, and Miss P. M. Sturdy, with others both in the wards and the laboratory who played an indispensable part.

REFERENCES

Andrew, J. D., and Gardner, P. S. (1963). Occurrence of respiratory syncytial virus in acute respiratory disease in infancy. Brit. med. $7 ., 2,1447$.

Banatvala, J. E., Anderson, T. B., and Reiss, B. B. (1964). Parainfluenza infections in the community. Brit. med. $\mathcal{F}$., 1, 537.

Baron, S. (1966). Interferon. North Holland Publishing Company, Amsterdam.

- , and Isaacs, A. (1962). Absence of interferon in lungs from fatal cases of influenza. Brit. med. $\mathcal{F} ., 1,18$.

Beale, A. J., McLeod, D. L., Stackiw, W., and Rhodes, A. J. (1958). Isolation of cytopathogenic agents from the respiratory tract in acute laryngotracheobronchitis. ibid., $1,302$.

Becroft, D. M. O. (1967). Histopathology of fatal adenovirus infection of the respiratory tract in young children. $\mathcal{F}$. clin. Path., 20, 561.

Beem, M., Wright, F. H., Hamre, D., Egerer, R., and Oehme, M. (1960). Association of the chimpanzee coryza agent with acute respiratory disease in children. New Engl. F. Med., 263, 523.

Bell, J. A., Huebner, R. J., Rosen, L., Rowe, W. P., Cole, R. M., Mastrota, F. M., Floyd, T. M., Chanock, R. M., and Shvedoff, R. A. (1961). Illness and microbial experience of nursery children at Junior Village. Amer. F. Hyg., 74, 267.

Bellanti, J. A., Artenstein, M. S., and Buescher, E. L. (1965) Characterisation of virus neutralizing antibodies in human serum and nasal secretions. F. Immunol., 94, 344.

Bradburne, A. F., Bynoe, M. L., and Tyrrell, D. A. J. (1967). Effects of a "new" human respiratory virus in volunteers. Brit. med. F., 3, 767.

Bradstreet, C. M. P., and Taylor, C. E. D. (1962). Technique of complement-fixation test applicable to the diagnosis of virus diseases. Mth. Bull. Minist. Hlth Lab. Serv., 21, 96.

Brimblecombe, F. S. W., Cruikshank, R., Masters, P. L., Reid, D. D. Stewart, G. T., and Sanderson, D. (1958). Family studies of respiratory infections. Brit. med.f., 1, 119.

Bynoe, M. L., Hobson, D., Horner, J., Kipps, A., Schild, G. C. and Tyrrell, D. A. J. (1961). Inoculation of human volunteers with a strain of virus isolated from a common cold. Lancet, 1, 1194.

Carmichael, J., McGuckin, R., and Gardner, P. S. (1968). Outbreak of Coxsackie type B2 virus in a children's home in Newcastle upon Tyne. Brit. med. f., 2, 532. 
Chanock, R. M., Kim, H. W., Vargosko, A. J., Deleva, A., Johnson, K. M., Cumming, C., and Parrott, R. H. (1961). Respiratory syncytial virus. I. Virus recovery and other observations during 1960 outbreak of bronchiolitis, pneumonia, and minor respiratory diseases in children. F. Amer. med. Ass., 176, 647.

-, Parrott, R. H., Cook, K., Andrews, B. E., Bell, J. A. Reichelderfer, T., Kapikian, A. Z., Mastrota, F. M., and Huebner, R. J. (1958). Newly recognised myxoviruses from children with respiratory disease. New Engl. F. Med., 258, 207.

, $\longrightarrow$, Johnson, K. M., Kapikian, A. Z., and Bell, J. A. (1963). Myxoviruses: parainfluenza. Amer. rev. resp. Dis., 88, (Suppl.), 152.

Chany, C., Lépine, P., Lelong, M., Le-Tan-Vinh, Satgé, P., and Virat, J. (1958). Severe and fatal pneumonia in infants and young children associated with adenovirus infection. Amer. F. Hyg., 67, 367 .

Clarke, S. K. R., Corner, B. D., Gambier, D. M., Macrae, J., and Peacock, D. B. (1964). Viruses associated with acute respiratory infections. Brit. med. f., 1, 1539.

Cramblett, H. G., Rosen, L., Parrott, R. H., Bell, J. A., Huebner, R. J., and McCullough, N. B. (1957). Echo viruses associated with respiratory disease in children. Amer. F. Dis. Child., 94, 407.

Deinhardt, F., May, R. D., Calhoun, H. H., and Sullivan, H. E. (1958). The isolation of adenovirus type 1 from a fatal case of viral "pneumonitis". Arch. intern. Med., 102, 816.

Dingle, J. H., Badger, G. F., and Jordan, W. S. (1964). Illness in the Home. The Press of Western Reserve University, Cleveland.

Disney, M. E., Sandiford, B. R., Cragg, J., and Wolff, J. (1960). Epidemic bronchiolitis in infants. Brit. med. F., 1, 1407.

Doane, F. W., Anderson, N., Chatiyanonda, K., Bannatyne, R. M. McLean, D. M., and Rhodes, A. J. (1967). Rapid laboratory diagnosis of paramyxovirus infections by electron microscopy. Lancet, 2, 751.

Douglas, J. W. B., and Blomfield, J. M. (1958). Children under Five. Allen and Unwin, London.

Dreizen, R. S., Zhukova, E. K., and Kniazeva, L. D. (1960). On the problem of pneumonia connected with adenovirus infections in children. (In Russian). Vop. Okhran'y Materin. Dets., 5, 19.

Elderkin, F. M., Gardner, P. S., Turk, D. C., and White, A. C. (1965). Aetiology and management of bronchiolitis and pneumonia in childhood. Brit. med. $\mathcal{F} ., 2,722$.

Enders, J. F., Weller, T. H., and Robbins, F. C. (1949). Cultivation of the Lansing strain of poliomyelitis virus in cultures of various human embryonic tissues. Science, 109, 85.

Finland, M., Peterson, O. L., and Strauss, E. (1942). Staphylococcic pneumonia occurring during an epidemic of pneumonia. Arch. intern Med., 70, 183.

Francis, T., Jr. (1940a). A new type of virus from epidemic influenza. Science, 92, 405.

- (1940b). Inactivation of epidemic influenza virus by nasal secretion of human individuals. ibid., 91, 198.

(1963). Epidemic influenza. Amer. Rev. resp. Dis., 88, (suppl.), 148.

Gardner, P. S., and Cooper, C. E. (1964). The feeding of oral poliovirus vaccine to a closed community excreting faecal viruses. F. Hyg. (Lond.), 62, 171.

-, Elderkin, F. M., and Wall, A. H. (1964). Serological study of respiratory syncytial virus infections in infancy and childhood. Brit. med.F., 2, 1570.

—, Knox, E. G., Court, S. D. M., and Green, C. A. (1962) Virus infection and intussusception in childhood. ibid., 2, 697. , and McQuillin, J. (1968). The application of the immunofluorescent antibody technique in the rapid diagnosis of respiratory syncytial virus infection. ibid., 3, 340 .

—, Stanfield, J. P., Wright, A. E., Court, S. D. M., and Green, C. A. (1960). Viruses, bacteria, and respiratory disease in children. ibid., 1, 1077.

, Turk, D. C., Aherne, W. A., Bird, T., Hodaway, M. D., and Court, S. D. M. (1967). Deaths associated with respiratory tract infection in childhood. ibid., 4, 316.

, Wright, A. E., and Hale, J. H. (1961). Faecal excretion of adenovirus in a closed community, ibid., 2, 424.

Grist, N. R., Ross, C. A. C., and Stott, E. J. (1967). Influenza, respiratory syncytial virus, and pneumonia in Glasgow, 1962-5. ibid., 1, 456.
Güthert, H., Meerback, W., and Wöckel, W. (1964). Zur morphologie der Lunge bei Virusinfektionen. Z. ges. inn. Med., 19, 865.

Hambling, M. H. (1964). A survey of antibodies to respiratory syncytial virus in the population. Brit. med. ., $^{1}, 1223$.

Hayflick, L., and Moorhead, P. S. (1961). The serial cultivation of human diploid cell strains. Exp. Cell Res., 25, 585.

Heggie, A. D., Schultz, I., Gutekunst, R. R., Rosenbaum, M., and Miller, L. F. (1960). An outbreak of a summer febrile disease caused by coxsackie B2 virus. Amer. F. publ. Hlth, 50, 1342.

Hers, J. F. P., Kuip, L. Van der, and Masurel, M. (1968). Rapid diagnosis of influenza. Lancet, 1, 510.

Heycock, J. B., and Noble, T. C. (1962). 1,230 cases of acute bronchiolitis in infancy. Brit. med. F., 2, 879.

Higgins, P. G., Boston, D. G., and Ellis, E. M. (1964). The isolation of viruses from acute respiratory infections. II. A study of the isolations made from cases occurring in a general practice in 1963. Mth. Bull. Min. Hlth Lab. Surv., 23, 93.

Hilleman, M. R. (1963). Respiratory syncytial virus. Amer. Rev. resp. Dis., 88, (suppl.), 181.

, Reilley, C. M., Stokes, J., Jr., and Hamparian, V. V. (1963). Clinical-epidemiologic findings in coryzavirus infections ibid., 88, (suppl.), 274.

- , and Werner, J. H. (1954). Recovery of new agent from patients with acute respiratory illness. Proc. Soc. exp. Biol. (N.Y.) $85,183$.

Holdaway, D., Romer, A. C., and Gardner, P. S. (1967). The diagnosis and management of bronchiolitis. Pediatrics, 39, 924.

Holzel, A., Parker, L., Patterson, W. H., Cartmel, D., White, L. L. R., Purdy, R., Thompson, K. M., and Tobin, J. O'H. (1965). Virus isolations from throats of children admitted to hospital with respiratory and other diseases, Manchester 1962-64. Brit. med.F., 1, 614 .

- - White, L. L. R., Thompson, K. M., and Tobin, J. O'H. (1963). The isolation of respiratory syncytial virus from children with acute respiratory disease. Lancet, 1, 295.

Hsiung, C. C. (1963). Adenovirus pneumonia in infants and children: pathologic studies of 40 cases. Chin. med. F., 82, 390.

Jackson, G. G., Muldoon, R. L., Johnson, G. C., and Dowling, H. F. (1963). Contributions of volunteers to studies on the common cold. Amer. Rev. resp. Dis., 88, (suppl.), 120.

Johnson, K. M., Bloom, H. H., Mufson, M. A., and Chanock, R. M. (1962). Natural reinfections of adults by respiratory syncytial virus. New Engl. F. Med., 267, 68.

Kendall, E. J. C., Cook, G. T., and Stone, D. M. (1960). Acute respiratory infections in children: isolation of coxsackie $B$ virus and adenovirus during a survey in a general practice. Brit. med.F., 2, 1180.

—, Riddle, R. W., Tuck, H. A., Rodan, K. S., Andrews, B. E., and McDonald, J. C. (1957). Pharyngo-conjunctival fever: school outbreaks in England during the summer of 1955 associated with adenovirus types 3, 7 and 14. ibid., 2, 131.

Kleinschmidt, W. J., Cline, J. C., and Murphy, E. B. (1964). Interferon production induced by statolon. Proc. nat. Acad. Sci. (Wash.), 52, 741.

Koch, R., Kogut, M., and Asay, L. (1961). Management of bacterial meningitis in children. Pediat. Clin. N. Amer., 8, 1177.

Kravetz, H. M., Knight, V., Chanock, R. M., Morris, J. A., Johnson, K. M., Rifkind, D., and Utz. J. P. (1961). Respiratory syncytial virus. III. Production of illness and clinical observations in adult volunteers. F. Amer. med. Ass., 176, 657.

Lampson, G. P., Tytell, A. A., Field, A. K., Nemes, M. M., and Hilleman, M. R. (1967). Inducers of interferon and host resistance. I. Double-stranded RNA from extracts of Penicillium funiculosum. Proc. nat. Acad. Sci. (Wash.), 58, 782.

Lancet (1967). Leading article. A defence against viruses. 1, 549.

Lidwell, O. M., Morgan, R. W., and Williams, R. E. O. (1965). The epidemiology of the common cold. IV. The effect of weather. f. Hyg. (Lond.), 63, 427.

Lindsay, J. W., Rice, E. C., and Selinger, M. A. (1940). The treatment of meningitis due to Hemophilus influenzae. $\mathcal{F}$. Pediat., $17,220$.

Liu, C. (1956). Rapid diagnosis of human influenza infection from nasal smears by means of fluorescein-labeled antibody. Proc. Soc. exp. Biol. (N.Y.), $92,883$.

Loda, F. A., Clyde, W. A., Jr., Glezen, W. P., Senior, R. J., Sheaffer, C. I., and Denny, F. W., Jr., (1968). Studies on the role of 
viruses, bacteria, and $M$. pneumoniae as causes of lower respiratory tract infections in children. $\mathcal{F}$. Pediat., 72, 161.

McClelland, L., Hilleman, M. R., Hamparian, V. V., Ketler, A., Reilly, C. M., Cornfeld, D., and Stokes, J., Jr. (1961). Studies of acute respiratory illnesses caused by respiratory syncytial virus. II. Epidemiology and assessment of importance. New Engl.F. Med., 264, 1169.

McIntosh, K., Becker, W. B., and Chanock, R. M. (1967). Growth in suckling-mouse brain of "IBV-like" viruses from patients with upper respiratory tract disease. Proc. nat. Acad. Sci. (Wash.), 58, 2268.

McQuillin, J., and Gardner, P. S. (1968). Rapid diagnosis of respiratory syncytial virus infection by immunofluorescent antibody techniques. Brit. med.F., 1, 602.

Magill, T. P. (1940). A virus from cases of influenza-like upper respiratory infection. Proc. Soc. exp. Biol. (N.Y.), 45, 162.

Masters, P. L., Brumfitt, W., Mendez, R. L., and Likar, M. (1958). Bacterial flora of the upper respiratory tract in Paddington families, 1952-4. Brit. med. F., 1, 1200.

Medical Research Council Working Party on Acute Respiratory Virus Infections, A report (1965). A collaborative study of the aetiology of acute respiratory infections in Britain, 1961-4. Brit. med. F., 2, 319.

Miller, F. J. W., Court, S. D. M., Walton, W. S., and Knox, E. G. (1960). Growing Up in Newcastle upon Tyne. Published for the Nuffield Foundation by Oxford University Press, London.

Miller, W. R., and Jay, A. R. (1962). Staphylococcal pneumonia in influenza. Arch. intern. Med., 109, 276.

Morris, J. A., Blount, R. E., Jr., and Savage, R. E. (1956). Recovery of cytopathogenic agent from chimpanzees with coryza. Proc. Soc. exp. Biol. (N.Y.), 92, 544.

Moss, P. D., Adams, M. O., and Tobin, J. O'H. (1963). Serological studies with respiratory syncytial virus. Lancet, 1, 298.

Newcastle upon Tyne Hospital Respiratory Survey, 1959-67. In preparation for press.

Newcastle upon Tyne, Medical Officer of Health, Annual Reports, 1931-65.

Nichol, K. P., and Cherry, J. D. (1967). Bacterial-viral interrelations in respiratory infections of children. New Engl. $\mathcal{f}$. Med., 277, 667.

Parker, W. L., Wilt, J. C., and Stackiw, W. (1961). Adenovirus infections. Canad. F. publ. Hlth, 52, 246.

Parrott, R. H., Vargosko, A. J., Kim, H. W., Cumming, C., Turner, H., Huebner, R. J., and Chanock, R. M. (1961). Respiratory syncytial virus. II. Serologic studies over a 34-month period of children with bronchiolitis, pneumonia, and minor respiratory diseases. F. Amer. med. Ass., 176, 653.

Peacock, D. B., and Clarke, S. K. R. (1961). Respiratory syncytial virus in Britain. Lancet, 2, 466.

Philipson, L. (1958). Association between a recently isolated virus and an epidemic of upper respiratory disease in a day nursery. Arch. ges. Virusforsch., 8, 204.

Registrar General's Report, England and Wales (1966).

Reynolds, E. O. R., and Cook, C. D. (1963). The treatment of bronchiolitis. F. Pediat., 63, 1205.

Ross, C. A. C., Stott, E. J., McMichael, S., and Crowther, I. A. (1964). Problems of laboratory diagnosis of respiratory syncytial virus infection in childhood. Arch. ges. Virusforsch., 14, 553.

Rowe, W. P., Huebner, R. J., Gilmore, L. K., Parrott, R. H., and Ward, T. G. (1953). Isolation of a cytopathogenic agent from human adenoids undergoing spontaneous degeneration in tissue culture. Proc. Soc. exp. Biol. (N.Y.), 84, 570.

Rytel, M. W., Shope, R. E., and Kilbourne, E. D. (1966). An antiviral substance from Penicillium funiculosum. V. Induction of interferon by helenine. f. exp. Med., 123, 577.

Sell, S. H. W. (1960). Some observations on acute bronchiolitis in infants. Amer. F. Dis. Child., 100, 7.

Simpson, H., and Flenley, D. C. (1967). Arterial blood-gas tensions and $\mathrm{pH}$ in acute lower-respiratory-tract infections in infancy and childhood. Lancet, $1,7$.
Smith, C. B., Friedewald, W. T., and Chanock, R. M. (1967). Inactivated Mycoplasma pneumoniae vaccine: evaluation in volunteers. F. Amer. med. Ass., 199, 353.

-, Purcell, R. H., Bellanti, J. A., and Chanock, R. M. (1966). Protective effect of antibody to parainfluenza type 1 virus. New Engl. F. Med., 275, 1145.

Smith, W., Andrewes, C. H., and Laidlaw, P. P. (1933). A virus obtained from influenza patients. Lancet, 2,66 .

Smorodintsev, A. A., and Chalkina, O. M. (1955). Basic principles of constructing a live vaccine against influenza. (Russian.) In Voprosy Patogeneza: Immunologii Virusnyk Infektsii, p. 329. Ed. by A. A. Smorodintsev. Medgiz, Leningrad. (Quoted by Smith et al., 1966.)

Sobel, G., Aronson, B., Aronson, S., and Walker, D. (1956). Pharyngoconjunctival fever: report of an epidemic outbreak. Amer. F. Dis. Child., 92, 596.

South, M. A., Cooper, M. D., Woleheim, F. A., Hong, R., and Good, R. A. (1966). The 1gA system. I. Studies of the transport and immunochemistry of IgA in the saliva. F. exp. Med., 123, 615.

Stott, E. J., Bell, E. J., Eadie, M. B., Ross, C. A. C., and Grist, N. R. (1967). A comparative virological study of children in hospital with respiratory and diarrhoeal illnesses. F. Hyg. (Lond.), 65, 9.

Sultan, R. R. P. (1966). Acute respiratory disease and clinical biometeorology. II. Proceedings of the Third International Biometeorological Congress, Paris, 1963. Pergamon Press, Oxford.

Taylor, R. M. (1949). Studies on survival of influenza virus between epidemics and antigenic variants of the virus. Amer. $\mathcal{F}$. publ. Hlth, 39, 171.

Teng, C. H. (1960). Adenovirus pneumonia epidemic among Peking infants and pre-school children in 1958. Chin. med. F., $80,331$.

Tomasi, T. B., Jr., Tan, E. M., Solomon, A., and Prendergast, R. A. (1965). Characteristics of an immune system common to certain external secretions. F. exp. Med., 121, 101.

Turk, D. C. (1963). Naso-pharyngeal carriage of Haemophilus influenzae type B. F. Hyg. (Lond.), 61, 247.

-, and May, J. R. (1967). Haemophilus Influenzae: Its Clinical Importance. English University Press, London.

Tyrell, D. A. J. (1963). Further experiments on viruses isolated from common colds (rhinoviruses). Perspect. Virol., 3, 238.

, and Bynoe, M. L. (1961). Some further virus isolations from common colds. Brit. med. F., 1, 393.

-, Buckland, F. E., and Hayflick, L. (1962). The cultivation in human-embryo cells of a virus (D.C.) causing colds in man. Lancet, 2, 320.

, - Hitchcock, G., Pereira, H. G., and Andrewes, C. H. (1960). Some virus isolations from common colds. I. Experiment employing human volunteers. ibid., 1, 235.

- - and Hoorn, B. (1968). Cultivation of "difficult" viruses from patients with common colds. Brit. med. f., 1, 606.

Van der Veen, J. (1963). The role of adenoviruses in respiratory disease. Amer. Rev. resp. Dis., 88, (suppl.), 167.

—, and Smeur, F. A. A. M. (1961). Infections with parainfluenza viruses in children with respiratory illness in Holland. Amer. F. Hyg., 74, 326.

Vargosko, A. J., Kim, H. W., Parrott, R. H., Jeffries, B. C., Wong, D., and Chanock, R. M. (1965). Recovery and identification of adenovirus in infections of infants and children. Bact. Rev., $29,487$.

Vogel, J., and Shelokov, A. (1957). Adsorption-hemagglutination test for influenza virus in monkey kidney tissue culture. Science, 126, 358.

Wolontis, S., Tunevall, G., and Sterner, G. (1967). Adenovirus type 5 infections an outbreak of febrile pharyngitis in a home for infants. Acta paediat. (Uppsala), 56, 57.

Wood, S. H., Buddingh, G. J., and Abberger, B. F., Jr. (1954). An enquiry into the aetiology of acute bronchiolitis of infants. Pediatrics, 13, 363. 